\title{
Introduction: the business of researching family enterprises
}

\author{
Panikkos Zata Poutziouris, Kosmas X. Smyrnios and \\ Sabine B. Klein
}

The Handbook of Family Business Research is a substantial collection of papers manifesting recent advances in the theory and practice of family business research. This compilation is, to a large extent, in response to the extensive growth of the family business discipline as a topic of academic inquiry. The principal objective underlying this volume was to provide readers with a compilation of authoritative and scholarly papers, providing an overview of current thinking and contributing to the further advancement of the field.

\section{Emergence of a family business theme}

Family enterprises, irrespective of scale of operation, legal form, industrial activity, and level of socio-political and market development have been the backbone of corporate life, across nations, remaining a cornerstone of socio-economic development. Historically, family firms are, for the most part, enduring institutions. Their importance parallels socio-cultural advances, technological advances, and the so-called new market order associated with globalization.

Family business research, as an academic field of inquiry, is relatively young. The emergence of this topic of research can be attributed largely to the proactive approach of family business practitioners whose early efforts focused on practice-based articles and case studies, as noted by Donnelley (1964) and Barnes and Hershon (1976).

Arguably, in the early days, treatment of this topic from the practitioners' side has often been subjected to journalistic exploitation, whilst from an academic perspective research has tended to be data driven. Despite adoption of increasingly sophisticated empirical and analytic procedures, causal-based research has remained myopic. However, articulation of conceptual and theoretical papers is gaining momentum.

The field of family business research was retarded by a series of factors, including a chronic failure by scholars and practitioners to establish a consensus as to what constitutes a family business; adoption of methodologies not supported by theory; survey designs lacking robustness; application of relatively unsophisticated statistical methods; and a dearth of large-scale (longitudinal) databases to enable cross-sectional and time-series econometric analyses, enabling significant comparisons between family and other enterprises (Brockhaus, 1994). Moreover, the focus of researchers was geared towards addressing phenomenological problems rather than systematically exploring and advancing theoretical paradigms. Specifically, early research tended to focus their lines of inquiry on succession, business governance and related structures, and performance, but failed to identify important variables and their interrelationships, leading to sound theoretical conceptualizations. Today, prominent mainstream journals publish family business research 


\section{Handbook of research on family business}

owing to its rigour, richness and relevance. Investigators have moved beyond descriptive case study and survey research, employing triangulation approaches driven by theory.

\section{Recent developments}

During the new millennium, family firm research has demonstrated significant advances, not only in terms of quality, but also in articulation of new developments and establishment of prominent international bodies. Below, we outline a number of these developments.

(a) Following the early push of a family business agenda by the Family Firm Institute (FFI) which has traditionally been geared to educationalists and practitioners, we saw the emergence of the Family Business Network (FBN) International, establishing close links with family business owner-managers and academics. Since these times, the International Family Enterprise Research Academy (IFERA), a group of academics committed to the advancement of family business as a science-based discipline, has arisen.

(b) The International Family Research Enterprise Academy has been actively campaigning for the advancement of family business through international collaborative projects and work with emerging researchers. Its vision is to be a driving force of an international network that ensures that family business, as a multi disciplinary field, becomes a leading topic of business research. The Academy comprises a global network for scholars (including new doctoral students), committed to family business research, providing investigators with valuable resources; and access to literature, family businesses, business families, and a network of scholars. Through its association with FBN-International in staging annual Global FBN research forums, IFERA has helped to bridge the gap between research, theory and practice, on the one hand, and professionals that service these businesses, business families, owner-managers and the community, on the other. The valuable contribution made by IFERA is amply demonstrated by the quality of refereed conference proceedings and publications (see Poutziouris, 2000; Corbetta and Montemerlo, 2001; Koiranen and Karlsson, 2002; Poutziouris and Steier, 2003; Tomasselli and Melin, 2004).

(c) Another indicator afforded to the recognition of this field is the inclusion of the Family Business Review journal in the Social Citation Index by Thomson ISI, recognizing the academic standard of FBR by the scientific community.

(d) The Canadian Theorization Initiative, in response to calls for the deployment of alternative research methodologies essential for theory development and research per se, has published a series of special issues in the Journal of Business Venturing, and the Entrepreneurship Theory and Practice journal. Similarly, in the North America, the Family Enterprise Research Conference has helped to promote family business at the Academy of Management-Entrepreneurship Division.

Consistent with these developments, research in this field has broken through the glass ceiling and is being published in top-tier journals, particularly in areas focusing on listed family businesses and their performance (Anderson and Reeb, 2003; Anderson et al., 2003; Burkart et al., 2003; Gomez-Mejia et al., 2001; Villalonga and Amit, 2004), agency costs (Morck and Yeung, 2003) and nepotistic altruism (Schulze et al., 2003). These 
notable investigations, inter alia, have helped elevate the family business theme. Within this backdrop, the Handbook of Family Business Research raises the bar further, demonstrating an interdisciplinary and multidimensional field of research, traversing process theory, case studies, application of quantitative and qualitative procedures that employ primary, secondary, narrative and ethnographic methods, along with papers that contribute to the validation of theoretical constructs.

Unequivocally, this volume contributes significantly to the advancement of family business research, theory, and practice. This selection of extant research and conceptual articles:

- helps to validate the protagonist role family firms play in social-economic milieus;

- provides an in depth treatment of operational and definitional issues surrounding what constitutes a family business;

- offers a systematic account of the historical development of the field of family business;

- embraces methodologies encompassing micro and macro perspectives;

- introduces theoretical bases, conceptualizations, and paradigms underpinning family business entrepreneurship, the papers of which challenge the orthodox microeconomic view of homo-economicus firms by highlighting the virtues of family influence, familiness and social capital; and

- finally, proffers a selection of empirical studies addressing the current family business research agenda.

\section{Structure of the book}

The Handbook of Research on Family Business involves 33 substantial contributions, five of which are reprints published in top-tier journals. This collection is organized in seven parts: 'Frontiers of Family Business'; 'Theorizing Family Businesses and Business Families'; 'Family Business Research: Metrics and Methodologies'; 'Family Business Themes in Focus'; 'Family Business Succession'; 'Family Business Performance: Global and Trans-cultural Issues'; and 'Family Business Finance'.

Part One 'Frontiers of a Family Business' establishes the academic scene and reviews developments of the family business field.

- Frank Hoy and Pramodita Sharma provide a chronology detailing the evolution of educational programmes and research.

- Pramodita Sharma, based on a review of 217 published studies, reflects on the status of the field and scope of family business.

- Joseph Astrachan and Melissa Shanker present an empirical research framework for assessing the economic role of family firms.

Part Two 'Theorizing Family Businesses and Business Families' is a selection of papers dealing with pertinent theoretical constructs concerning family business entrepreneurship.

- Timothy Habbershon, Mary Williams and Ian MacMillan propose a unified systems perspective of family firm performance, their model of which encapsulates the notion of familiness, and the systemic relationship between resources and capabilities as sources of advantage (or constraint) and performance. 
- Ramona Heck, Sharon M. Danes, Margaret Fitzgerald, George Haynes, Cynthia Jasper, Holly Schrank, Kathryn Stafford and Mary Winter, based on the Sustainable Family Business Model, proffer an analytical framework for the study of the family's dynamic role within family business entrepreneurship.

- Nigel Nicholson and Åsa Björnberg introduce the concept of Critical Leader Relationships (CLRs), capturing the neglected theme of shared leadership. These investigators explore possible dyad types in family business CLRs, and propose a Situation-Process-Qualities (SPQ) model of leadership effectiveness as applied to CLRs.

- Lorraine Uhlaner proposes a theoretical framework within which the business family, as a team, can be explored to identify aspects that impact on business strategy and performance.

- Alberto Gimeno Sandig, Gaston Labadie, Willem Saris and Xavier Mendoza Mayordomo advance a theoretical model, incorporating business and family complexity, and identifying internal factors that explain family business performance.

Part Three 'Family Business Research: Metrics and Methodologies' comprises a collection of papers dealing with definitional, methodological, and measurements issues.

- Joseph Astrachan, Sabine Klein and Kosmas Smyrnios report on their pioneering work concerning the Family: Power-Experience-Culture (F-PEC) scale, a systematic measure of family influence on businesses.

- Paul Westhead and Carole Howorth examine variables relating to family firm objectives and ownership, and management structures, leading to an identification of a taxonomy of private family firm types.

- Ken Moores and Justin Craig demonstrate how elements of the Balanced Scorecard, an accepted strategic management and measurement tool, can be adapted to the family business context for use as a strategic tool and as a means of contributing to the professionalization of family firms.

- Sandra Moncrief-Stuart, Joe Paul and Justin Craig present a methodological paper validating the Aspen Family Business Inventory, an assessment tool designed specifically for use by consultants working with families in business.

Part Four 'Family Business Themes in Focus' incorporates a series of in-depth papers focusing on functional areas of the family business strategic management.

- Ercilia García-Álvarez and Jordi López-Sintas present evidence from in-depth cross case analysis to delineate a model encompassing value transmission and successors' socialization, for facilitating family business continuity.

- Annika Hall, Leif Melin and Mattias Nordqvist, utilizing a case study approach identifying key parameters associated with everyday, micro and human aspects of organizational life, submit a theoretical framework concerning family business strategizing and direction.

- Lucrezia Songini reflects on the theory and practice of professionalization processes in family firms. 
- Miguel Angel Gallo and Salvatore Tomaselli explore the theoretical and practical dimensions of protocols in family business strategic planning processes.

- Joseph Astrachan, Andrew Keyt, Suzanne Lane and Kristi McMillan focus on the governance schemes of family and non-family businesses, and tender propositions concerning accountability in firms.

- Rosa Nelly Trevinyo-Rodríguez and Josep Tàpies conceptualize a knowledge transfer model of family firms concentrating on internal and external relationships in family-enterprise next-generation systems.

- Franz Kellermanns and Kimberly Eddleston furnish a conceptual paper targeting management strategies relating to task and relationship conflict in family firms.

Part Five 'Family Business Succession' incorporates a collection of in-depth papers focusing on the popular theme of strategic succession planning:

- Danny Miller, Lloyd Steier and Isabelle Le Breton-Miller, within the context of inductive and case study methodologies, examine the main issues associated with business successions that fail.

- Johan Lambrecht and Rik Donckels develop an explanatory model of business transfer derived from an examination of transitional paths associated with family business succession.

- Pietro Mazzola, Gaia Marchisio and Joseph Astrachan explore the specific benefits of strategic planning processes as a next-generation training tool, particularly during the post-succession stage of the business transfer planning process.

- Vassilios Pyromalis, George Vozikis, Theodoros Kalkanteras, Michaela Rogdaki and George Sigalas advance an integrated framework for evaluating the success of the family business succession process according to gender specificity.

Part Six ‘Family Business Performance: Global and Trans-cultural Issues’ presents internationally based research initiatives.

- Kristin Cappuyns, through a prism of multiple case studies of Spanish family firms, reports on internationalization via strategic alliances.

- David Pistrui, Wilfred Huang, Harold Welsch and Zhao Jing describe seminal attributes, characteristics and growth orientations of mainland Chinese entrepreneurs, highlighting the contributions of relationships, roles, family and culture in the development of private small and medium enterprises (SMEs).

- Guido Corbetta and Alessandro Minichilli examine the essential features of boards of directors in Italian publicly listed companies.

- Luca Gnan and Daniela Montemerlo compare Italian family versus non-family SMEs in terms of ownership and governance issues.

- Toshio Goto documents the historical development of the Japanese family business economy, providing solid explanations for its longevity.

Part Seven 'Family Business Finance' is a compilation of empirical papers exploring financial and related performance issues pertaining to privately held and quoted family companies. 
- Myriam Lyagoubi investigates relationships between family ownership and debt financing behaviour in French privately held and public companies.

- Panikkos Zata Poutziouris, in a study of the UK London main stock market, profiles the UK Family Business PLC economy, and through the lens of a Family Business Index, reports on their performance.

- Susana Menéndez-Requejo evaluates the impact of family governance and ownership on Spanish firm performance.

- María Sacristán Navarro and Silvia Gómez Ansón reviews the influence of family ownership, management and control on the performance of Spanish quoted companies.

\section{'Epilogue'}

- Shaker Zahra, Sabine Klein and Joseph Astrachan undertake an element of crystalball gazing and provide reflections on the future directions and new frontiers open to this field.

To sum up, this volume features a kaleidoscope of competitive research papers, dealing with conceptual and theoretical frameworks, new methodologies, leading to an identification of best research practice. As is evidenced by this collection, one imperative is the need to continue developing balanced family business entrepreneurship frameworks where new standards of research are achieved in order to strengthen theories relating to family-controlled firms. Another imperative calls for the use of alternative research methods incorporating sources of competitive advantage and dynamic capabilities of family firms, namely, familiness and family influence. This imperative is consistent with the words of Aristotle who is reported as saying that the family is the association established by nature for the supply of people's everyday wants (Aristotle, $400 \mathrm{BC}$ ). These words reflect the dual and interrelated nature of family business entrepreneurship.

In closing, we express our gratitude to the IFERA Board who have entrusted us with the co-ordination of this initiative, and of course, to Edward Elgar Publishing Limited for recognizing the emergence of the importance of the theme of family business entrepreneurship. Special thanks are extended to Jo Betteridge, Caroline Cornish and Francine O'Sullivan, and their Elgar editorial team. We appreciate the support of the publishers of the Journal of Entrepreneurship and Theory and Practice, Journal of Business Venturing and the Family Business Review journal for permission to utilize a number of reprints. We are also very grateful to the contributors for their co-operation and zeal to deliver topquality research papers. Many thanks are also extended to our reviewers who were generous with their time and provided valuable guidance to the authors and editorial team.

\section{Reviewers}

Åsa Björnberg, London Business School (UK)

Justin Craig, Oregon State University (USA)

Maria Ercilia Garcia, Universitat Rovira i Virgili de Tarragona, (Spain)

Christopher Graves, Adelaide University (Australia)

Annika Hall, Jönköping International Business School (Sweden) 
Thomas Zellweger, St Gallen University (Switzerland)

Ramona Heck, Baruch College (USA)

Carole Howorth, University of Lancaster (UK)

Bakr Ibrahim, Concordia University (Canada)

Peter Jaskiewicz, European Business School (Germany)

Andrew Keyt, Loyola University Chicago (USA)

Eleni Kostea, University of Cyprus (Cyprus)

Eddy Laveren, University of Antwerp ( Belgium)

Jordi Lopez, Universitat Autonoma de Barcelona (Spain)

Myriam Lyagoubi, EM LYON (France)

Gaia Marchisio, Kennesaw State University (USA)

Susana Menéndez Requejo, University of Oviedo (Spain)

Nicos Michaelas, Demetra Investment PLC (Cyprus)

Daniela Montemerlo, SDA Bocconi and University of Insubria (Italy)

Mikko Mustakallio, Helsinki Institute of Technology (Finland)

María Sacristán Navarro, University Rey Juan Carlos (Spain)

Mattias Nordqvist, Jönköping International Business School (Sweden)

David Pistrui, Illinois Institute of Technology (USA)

Lucrezia Songini, SDA Bocconi (Italy)

Khaled Soufani, Concordia University (Canada)

Lloyd Steier, University of Alberta (Canada)

Jill Thomas, Adelaide University, (Australia)

Rosa Nelly Trevinyo-Rodríguez, IESE (Spain)

Salvo Tomaselli, Palermo University (Italy)

Lorraine Uhlaner, Erasmus University Rotterdam (Netherlands)

Elina Varamaki, University of Vasa (Finland)

Yong Wang, Wolvehampton University, UK

So-Jin Yoo, NEWI, North East Wales Institute (UK)

On behalf of authors, reviewers, and the editorial team we trust that you find this volume of scholarly papers not only of interest, but also relevant.

\section{References}

Anderson, R. and Reeb, D. (2003), 'Founding-family ownership and firm performance: evidence from the S\&P 500', Journal of Finance, June (3), 1301-28.

Anderson, R., Mansi, S. and Reeb, D. (2003), 'Founding family ownership and the agency cost of debt', Journal of Financial Economics, 68, 263-85.

Barnes, L.B. and Hershon, S.A. (1976), 'Transferring power in the family business', Harvard Business Review, July/August, 105-114.

Brockhaus, R.H. (1994), 'Entrepreneurship and family business research: comparisons, critique, and lessons', Entrepreneurship Theory and Practice, 19(1), 25-38.

Burkart, M., Panunzi, F. and Shleifer, A. (2003), 'Family firms', Journal of Finance, 58(5), 2167-201.

Corbetta, G. and Montemerlo, D. (eds) (2001), The Role of the Family in the Family Business. Book of Research Forum Proceedings: 12th Annual Family Business Network World Conference, FBN Roma - SDA Bocconi Publication.

Donnelley, R.G. (1964), 'The family business', Harvard Business Review, 42, 93-105.

Gomez-Mejia, L., Nunez-Nickel, M. and Gutierrez, I. (2001), 'The role of family ties in agency contracts', Academy of Management Journal, 44, 81-95.

Koiranen, M. and Karlsson, N. (eds) (2002), The Future of the Family Business: Values and Social Responsibility. Research Forum Proceedings, Book of Research Forum Proceedings: 13th Annual Family Business Network World Conference, FBN Helsinki - University of Jyvaskyla Publication. 


\section{Handbook of research on family business}

Morck, R. and Yeung, B. (2003), 'Agency problems in large family business groups', Entrepreneurship Theory and Practice, 27(4), 367-82.

Poutziouris, P. (ed.) (2000), Family Business: Tradition or Entrepreneurship in the New Economy, Book of Research Forum Proceedings: 11th Annual Family Business Network World Conference, FBN London Manchester Business School Publication .

Poutziouris, P. and Steier, L. (eds) (2003), New Frontiers in Family Business Research: the Leadership Challenge, Book of Research Forum Proceedings: 14th Annual Family Business Network World Conference, FBN IFERA Lausanne Publication.

Schulze, W.S., Lubatkin, M.H. and Dino, R.N. (2003), 'Toward a theory of agency and altruism in family firms', Journal of Business Venturing, 18(4), 473-90.

Tomaselli, S. and Melin, L. (eds) (2004), Family Firms in the Wind of Change, Research Forum Proceedings, Book of Research Forum Proceedings: 15th Annual Family Business Network World Conference, FBN IFERA Copenhagen Publication.

Villalonga, B. and Amit, R.H. (2004), 'How do family ownership, control, and management affect firm value?', EFA 2004 Maastricht Meeting, Paper No. 3620. 